\title{
PILOT STUDY ON THE BASIS OF IPMA POLAND CERTIFICATION RESULTS
}

\author{
JOANNA RZEMPAŁA, ${ }^{1}$ ŁUKASZ D. SIENKIEWICZ ${ }^{2}$ \\ ${ }^{1}$ University of Szczecin, Faculty of Management and Economics of Services, International Project Management Association Poland, POLAND \\ email: joanna.rzempala@wzieu.pl \\ ${ }^{2}$ International Project Management Association Poland, POLAND \\ email: lukasz.sienkiewicz@ipma.pl
}

RECEIVED
ACCEPTED
JEL
CLASSIFICATION

KEYWORDS

ABSTRACT

\author{
4 December 2017 \\ 5 January 2018 \\ M20,M21, M520,M530
}

project managerial competence, technical competence, behavioral competence, contextual competence, certification of project managers

The authors discussed IPMA Competence Baseline, 4-L-C certification system, and substantive essentials of certification on IPMA-D level. In a part related to presentation of statistical pilot study, performed on the data collected between 2015-2016 by the Certification Office of IPMA Poland, potential areas of project managerial competence that need to be developed and improved have been identified, as well as the direction and scope of further study on much larger data sample.

\section{Introduction}

Project management is one of the most dynamically developing areas of management. The effective implementation of the project depends both on: the technical aspects of the realization and the competence of the people realizing the project (Goldsmith, Greenberg, Robertson, Hu-Chan, 2010). Individual competences of project managers and members of their teams are the basic factors determining the achievement of the project's success 
(Muller, Turner, 2010). Therefore, the competences of project management have become an area of interest for both theoreticians and practitioners (Chomicz, 2015). The following is the definition of individual competences developed by IPMA, published in IPMA Competence Baseline (ICB), ${ }^{1}$ presenting both elements of individual competency that are necessary for effective project management, but also their development.

The ICB guidelines contains a description of individual groups of competences, named as technical, behavioral and contextual, indicated as necessary for the effective implementation of the project. It is a universal model that can be used in all business sectors and industries. This means that the appropriate methods and tools can be chosen by the organization, and the individuals should select the appropriate components for a given situation from a wide range of available methodologies, methods, techniques and tools.

\section{Universal four-level-certification (4-L-C) system}

The 4-L-C system, developed and implemented by IPMA, arise from the need for a universal career development model for employees involved in project management. IPMA ICB distinguishes four levels of competence in project management (IPMA..., 2006, p. 13):

1. Level $D$ (Certified Project Manager Associate) - covering the competency necessary to properly perform project tasks and act as a member of the project team.

2. Level $\mathrm{C}$ (Certified Project Manager ) - characterizing the competences of the project manager of projects with limited complexity, and managing people including all stakeholders.

3. Level B (Certified Senior Project Manager ) - describing the level of competence of a senior (experienced) project manager who manages people from several organizations or organizational units and representing various fields of knowledge by working in a very complex project.

4. Level A (Certified Projects Director) - covering the competences of a person holding the function of program or portfolio director who manages a complex program or portfolio, managing project managers.

\section{Project Management Certification}

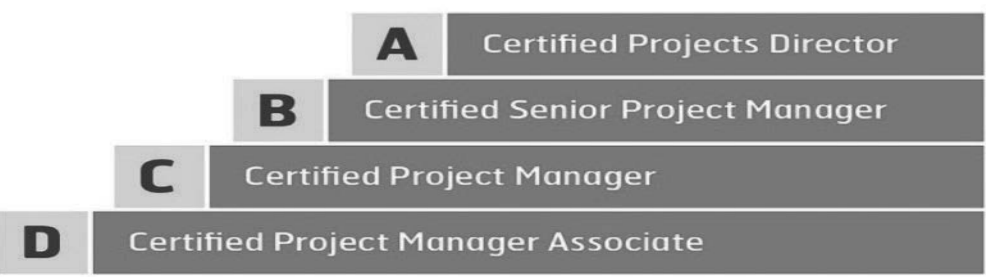

Figure 1. Certification levels

Source: www.ipma.world.

${ }^{1}$ International Project Management Association (IPMA) is an international non-profit organization associating national societies in the field of project management in 70 countries around the world. The mission of the society is to create a global space for activities that shape the future of project management. The main goal of the society is to build a platform for the exchange of experience in the field of project management and the creation of professional and ethical standards for project managers. 
The IPMA certification system (IPMA4-L-C) establishes a process of continuous improvement and development of project management competences. Successive levels of certification are a confirmation of competence, including knowledge and experience for each step of project managers career level. According to IPMA assessment of competences, simultaneously with the increase of the level of experience particular types of competences are more involved in the decision-making process, what implicates that the key element of the assessment is the professional experience of the person taking the certification exam.

\section{Level D - the certification exam}

The certification process phases include:

- Stage 1: collecting the application documents, e.g. CV that contain proven experience in project management, self-assessment, etc.

- Stage 2: depending on the level of certification, applicants need to pass a written exam and/or enter an assessment center.

- Stage 3: (optional for levels A, B, C): caring out in-depth interview with individuals.

The scope of research performed in the pilot phase covers only results gained during Level $D$ certification exam, therefore it requires more detailed description. It is expected that at this level of certification candidate will get more than $50 \%$ of positive score on the written exam which is divided into four parts:

- multiple-choice test in the area of selected individual competences,

- open questions in the form of an essay in selected competences groups,

- open tasks (descriptive) in the area of technical competences divided into subgroups, items related to: the project environment, stakeholders, and the objective and scope of the project,

- open tasks (computational) that require appropriate problem-solving approach to a case-study.

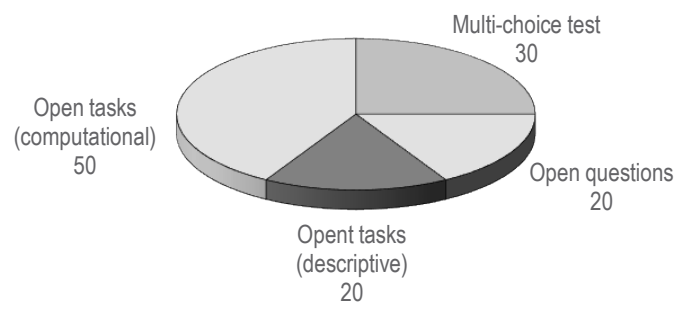

Figure 2. Scoring of individual parts of the IPMA D exam depending on the form of verification (in points)

Source: personal collection.

All competence elements described in the ICB are verified, during the exam. Each item of competence consists of knowledge and experience, mandatory for certification on level $\mathrm{D}$. The competences required in a given area are divided between areas in the following ratio: technical $-70 \%$, behavioral $-15 \%$ and contextual $-15 \%$. 


\section{Research method}

Undoubtedly, it was necessary to perform research on relatively wide range of data. Therefore, the most reasonable was to select nonprobability(purposive) sample of data to represent the whole population. The main reasons were: lack of complete set of records (data collected during the certification process was distributed between several databases), and relatively large diversification of records including representatives of all:

- industry sectors,

- job positions.

The authors of this publication carried out a pilot study. Main objectives were to: identify areas of competence that require development and improvement among people who perform or aspire to perform the function of project manager and set the direction of the next research study on a larger data sample. According to the adopted assumptions, the least developed areas should be reflected in the lower scores gained during the IPMA 4-LC certification process. The analysis of the results of the pilot study was to contribute to the development of the final version of the research model.

The pilot study was conducted on data collected during a certification process in years 2015-2016 (database contains 425 records). The consistency and completeness criterion of the data met 291 records. Among the investigated data were results gained by 64 women and 227 men. Among them 77 persons were acting as a project manager, 32 persons as a middle level manager, 36 persons as a senior manager, 52 persons were representing the position of a specialist, and 94 persons were acting as a project specialist. A full description of the research group is presented in Table 1.

Table 1. Characteristic of the population - pilot study

\begin{tabular}{|c|c|c|c|c|c|c|}
\hline \multirow[b]{2}{*}{ Industry sector } & \multicolumn{6}{|c|}{ Job Position } \\
\hline & $\begin{array}{c}\text { project } \\
\text { manager }\end{array}$ & $\begin{array}{c}\text { middle level } \\
\text { manager }\end{array}$ & $\begin{array}{c}\text { senior } \\
\text { manager }\end{array}$ & specialist & $\begin{array}{c}\text { project } \\
\text { specialist }\end{array}$ & sum \\
\hline Non-public administration & 3 & 2 & 4 & & & 9 \\
\hline Public administration & & 1 & & & 1 & 2 \\
\hline$R \& D$ & 1 & & & 3 & & 4 \\
\hline Building & 16 & 3 & 6 & 5 & 5 & 35 \\
\hline Advisory & & 6 & 2 & 8 & 3 & 19 \\
\hline Electrical power & 23 & 9 & 15 & 17 & 60 & 124 \\
\hline IT & 10 & 1 & 4 & 7 & 2 & 24 \\
\hline Construction & 1 & 4 & 1 & 2 & 2 & 10 \\
\hline Health care & & & & & 1 & 1 \\
\hline Automotive & 10 & 2 & & 4 & 11 & 27 \\
\hline Manufacturing & 10 & 2 & 1 & 5 & 3 & 21 \\
\hline Transportation & & 1 & 2 & & 1 & 4 \\
\hline Services & 3 & 1 & 1 & 1 & 5 & 11 \\
\hline Sum & 77 & 32 & 36 & 52 & 94 & 291 \\
\hline
\end{tabular}

Source: personal collection. 
The research procedure adopted during the pilot study assumed standardization of data (especially in terms of naming industry and positions in individual records), checking the normality of the distribution of collected data and the selection of appropriate statistical tools.

The scale of measurement used by IPMA Poland, for the assessment of individual competences, is ordinal. Assessment assumes values in the range of 0 to 10 with 0.5 -degree scale. The authors of this publication are aware that such nature of collected data limits significantly acceptable statistical operations, due to the lack of normal distribution in the observation (it was confirmed during data analysis in XLSAT 365 module/MS Excel tool). The authors decided to present selected results of the study in a simple form (i.e. report) prepared on the basis of raw data (Figures 3-8) and normalized data for the mean score values calculated from the results of the exams, in the distinction into industry sectors and job positions (Figures 9-10).

Mean values presented on charts have been scaled on the basis of frequency of individual results, categorized for the industry or position in the whole studied population. The mathematical transformations carried out on the data had been made as follows:

1. Calculation of the score gained during exam:

$$
V=\frac{V_{2}-V_{1}}{V_{1}}
$$

where:

$V_{1}$ - percentage value of contribution in all exams in 2015-2016,

$V_{2}$ - percentage value of average calculated on the basis of gained scores.

2. Min-max normalization to the values from min-max range - mean score values (V'):

$$
V^{\prime}=\frac{V-V_{\min }}{V_{\max }-V_{\min }} \times\left(m_{\max }-m_{\min }\right)+m_{\min }
$$

where:

$V$ - value from point 1 ,

$V_{\text {min }}$ - min value from input data range $V$,

$V_{\max }-$ max value from input data range $V$,

$m_{\min }-\min$ value of $V^{\prime}$ in normalized data, in this case it is the min value of the set of mean values calculated on the basis of the exam scores,

$m_{\max }-$ max value of $V^{\prime}$ in normalized data, in this case it is the max value of the set of mean values calculated on the basis of the exam scores.

The lack of a normal distribution of the collected data made it impossible to reliably evaluate gained results. Some percentage contributions of industries or job positions were at the level of $0.31 \%$ and those where the value was $16.70 \%$. Conclusions from data on such incomparable distributions were possible after standardization of the arithmetic mean value presented as percentage values (equation 1) and the linear transformation of the original data (equation 2) to the standardized values calculated in point 1. 
The collected results do not constitute a comprehensive static analysis possible for such a set of data, therefore authors decided to present them as a report with highlighting an important issue that should be considered and included in the final study (results of the final study will be developed and published in the future).

\section{The research results}

The first step in research was an analysis of the gained scores. The exam is evaluated positively if the total number of scores from all areas is above $50 \%$. In the studied population over $75 \%$ of people gained a positive result, and the average rating of all scores was 62.7 points (Figure 3 ).

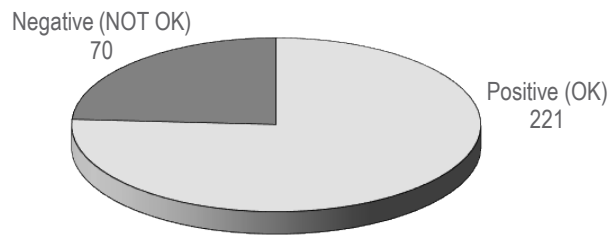

Figure 3. IPMA-D scores - number of OK and NOT OK results; population of 291 persons

Source: personal collection.

The scores gained in selected competence groups have been presented on Figure 4. The results indicate that the contextual competences were known the best. The lowest number of scores was noted within the technical competence.

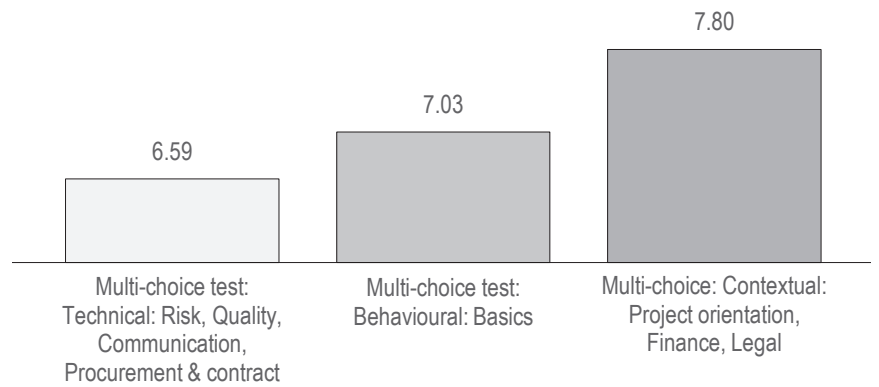

Competence areas

Figure 4. Results of multi-choice test - selected areas of individual competence (scores)

Source: personal collection.

In the open questions(descriptive), candidates write an essay about tough situations presented in the case study. The scores gained in behavioral and contextual competence area are much better then technical area (Figure 5). 


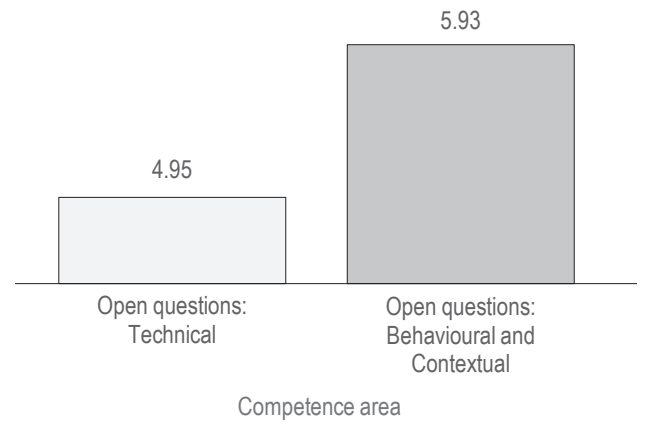

Figure 5. The open questions (descriptive) results (scores)

Source: personal collection.

Area of technical competence is also verified by open and computational tasks. Open tasks require the preparation of project context analysis with stakeholder analysis, as well as objectives and scope of the project. Collected numbers show that project managers gained the highest scores in objectives and scope analysis (i.e. 5.06/10 and 5.15/10) than other job positions (results have been presented on Figure 6).

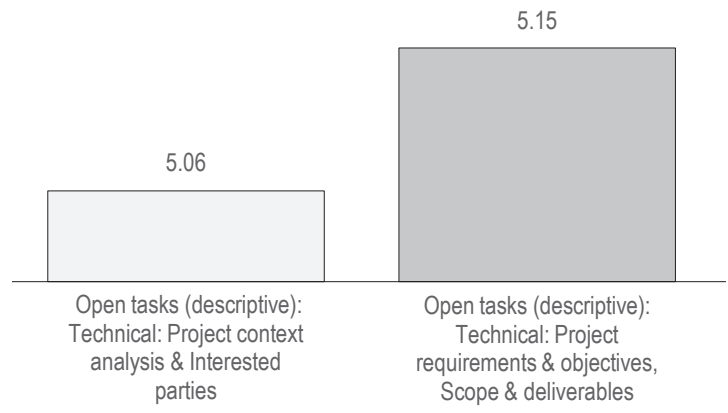

Competence area

Figure 6. The open questions results - selected technical competence (scores)

Source: personal collection.

Competence like scheduling, resource management, cost management, risk analysis and evaluation or project status are examined by open tasks(computational). The higher scores presented on Figure 7 are usually gained in scheduling. The worst results are usually gained in the cost planning and project monitoring (EV method). Nowadays cost management, as well as project monitoring is strongly supported by IT tools, therefore it might be the reason of such low scores in these areas. 


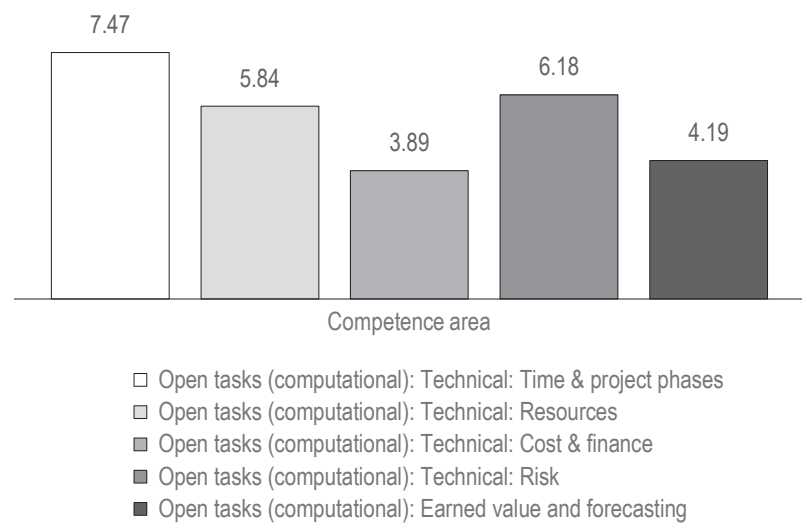

Figure 7. The open task(computational) results - technical competence (scores)

Source: personal collection.

Comparing the mean score values gained in different parts of exam, could be concluded the highest scores are gained in the multi-choice test part related to contextual competences. The worst score was gained in the area of competence elements related to planning and cost monitoring (Figure 8).

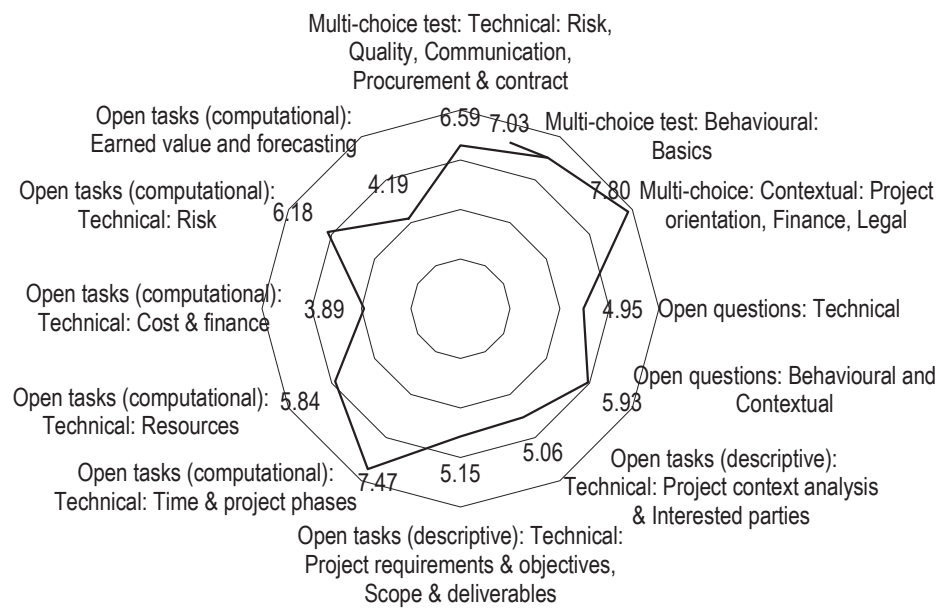

Figure 8. Mean score values in individual parts of the exam

Source: personal collection.

As a part of pilot study, the authors of this article analyzed scores gained during exam in distinction to individual industry sectors. The highest mean score values have been gained in electrical power and advisory industry sectors. The worst mean score values have been gained in construction industry sector (Figure 9). 


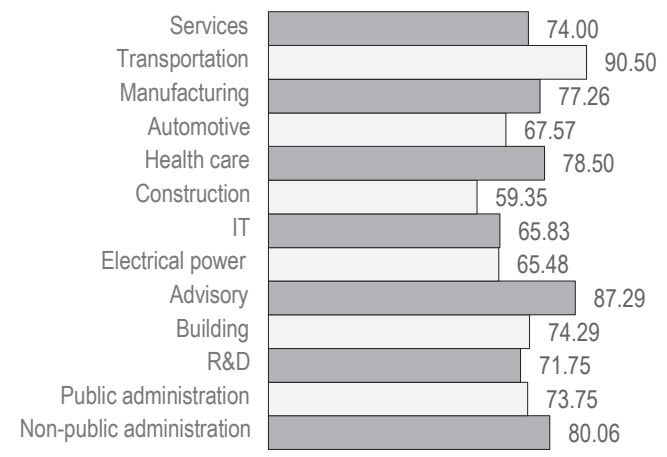

Figure 9 . The mean score values in distinction to industry sectors - normalized on the basis of the contribution to all exams in 2015-2016

Source: personal collection.

Analysis of the results on the basis of the job position distinction indicates that project managers and project management specialists gained the highest scores. Very similar scores have been gained by middle and senior managers (Figure 10).

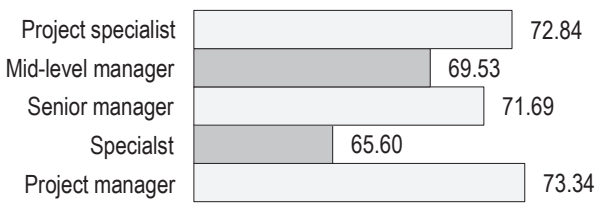

Figure 10. The mean score values in distinction to job position - normalized on the basis of the contribution to all exams in 2015-2016

Source: personal collection.

\section{Conclusion}

The analysis of pilot study outcomes allows to conclude as follows:

1. In the studied population, the worst developed is technical competence area, on the opposite side are the most developed contextual competence area. Lack of wide range of knowledge in technical competence could be a key failure factor (Musioł-Urbańczyk, 2010).

2. Contrary to popular opinion, behavioral competence are not the best developed ones (Klimiuk, 2009; Januszkiewicz, Kowalska, 2015).

3. The worst developed competence are related to cost management and project monitoring what has been confirmed by open tasks (computational).

4. Low scores gained in open tasks (computational) indicate poorly developed competence related to project managerial tools and techniques. 
5. The score values gained in open questions indicate poorly developed competence related to stakeholder analysis.

6. The mean score values differ significantly between different industry sectors, the root cause could be different level of maturity of organization.

7. The highest mean score values have been noticed in the group of project managers and project team members; it seems to confirm the foundation presented in ICB 4.0, where abilities, not only knowledge and skills are very important.

\section{References}

Chomicz, M. (2015). Ujęcie badawcze kompetencji kierowników projektów. e-mentor, 59, 42-55.

Goldsmith, M., Greenberg, C.L., Robertson, A., Hu-Chan, M. (2010). Globalni liderzy - kolejna generacja. Warszawa: MT Biznes.

IPMA Competence Baseline version 3.0. Internationa Project Management Association (2006).

Januszkiewicz, A., Kowalska, M. (2015). Kompetencje kierowników projektów unijnych. Organizacja i Zarządzanie, 59, 83-100.

Klimiuk, J. (2009). Rola kierownika projektu oraz zespołu projektowego w zarządzaniu projektami. Bezpieczeństwo i Technika Pożarnicza, 3, 35-45.

Muller, R., Turner, R. (2010). Leadership competency profiles of successful project managers. International Journal of Project Management, 28, 437-448.

Musioł-Urbańczyk, A. (2010). Kluczowe kompetencje kierownika projektu. Organizacja i Zarządzanie, 2, 93-108.

Cite this article aS: Rzempała, J., Sienkiewicz, Ł.D. (2018). Pilot study on the basis of IPMA POLAND certification results. European Journal of Service Management, 1 (25), 267-276. DOI: 10.18276/ejsm.2018.25-33. 